\title{
The Unsustainability of Kalego Traditional Game among Muna Community of Watopute District
}

\author{
La Ode Ali Basri ${ }^{1}$, Abdul Halim Momo ${ }^{2}$, Akhmad Marhadi ${ }^{3}$, Abdul Rahman ${ }^{3}$, La Ode Topo Jers ${ }^{3}$, Aslim $^{1}$ \& \\ Aswati $^{1}$ \\ ${ }^{1}$ Department of History, Faculty of Humanities, Halu Oleo University, Kendari \\ ${ }^{2}$ Department of Citizenship Education, Faculty of Teacher Training \& Education, Halu Oleo University, Kendari \\ ${ }^{3}$ Department of Anthropology, Faculty of Humanities, Halu Oleo University, Kendari \\ Correspondence: La Ode Ali Basri. Tel: 08-13-4179-7344. E-mail: basri.uho74@gmail.com
}

Received: October 19, 2017 Accepted: December 19, $2017 \quad$ Online Published: January 29, 2018

doi:10.5539/ass.v14n2p12 URL: https://doi.org/10.5539/ass.v14n2p12

\begin{abstract}
This study aims at analyzing the unsustainability causes of kalego as one of traditional games of Muna communities in Watopute District, Muna Regency, Southeast Sulawesi. Data collection was conducted through participant observation, interviews, surveys, and focused discussion. Data analysis was conducted qualitatively and descriptive statistic by employing data reduction technique, data presentation and conclusion. The results showed that kalego traditional game has been degraded or unsustainably practiced as the impact of the low awareness and low understanding among Muna community toward this traditional game. Approximately $71.25 \%$ Muna community in Watopute district cannot play the traditional game. The unsustainability of kalego was caused by several factors namely; 1 ) the absence of the family inheritance about kalego traditional game and the decreasing number of old figures who understand Muna culture contribute to the decreasing of local culture knowledge among younger generations; 2) Cultural encounters which results incorporated acculturation toward Muna's local culture; 3 ) the absence of the massive kalego game staging.
\end{abstract}

Keywords: unsustainability, traditional games and kalego

\section{Introduction}

The traditional game is one of the folklores that originates among society. Generally, traditional games are inherited from generation to generation, traditionally played and demonstrated by using some specific tools (Basri et al., 2017). In earlier times, the traditional game was one of the community amusements to relieve fatigue, create a common joy after work completion in fields or other devotional works. Nowadays, traditional games have begun to be abandoned by the community. Traditional games reflect the cultural expression as a bridge for people or communities to build a better understanding (Boro et al., 2015). As part of the local culture, traditional games appeared to have been degraded by the global culture which results the rapid extinction of traditional game. It is concerned by Sibarani (2012), who argues that the state should attribute culture as a national identity and should not share its development to the "global market mechanism". He argues that globalization, science, and technology have made most of people uprooted their cultural roots which implicate the extinction of local culture.

Various studies related to the unsustainability of local culture have been conducted, for example Escobar (2001), which shows that the traditional culture is always marginalized when dealing with globalization, because globalization with its capitalism has the ability to attack and to marginalize. Globalization that provides space and facilitates people's mobility frequency and communication, has created culture supermarket and contributed to the process of local cultures extinction (Wahab et al., 2012). Globalization has led to the higher intensity of value conflict between local and global culture. The local cultural value system that has been used as a guidance by the community has started to change due to the influence of global cultural values, especially with the progress of information and technology which accelerates the transformation process (Basri et al., 2017). Meanwhile, Premo and Kuhn (2010) state that innovation of technology is one of the factors that cause a cultural transformation. Cultural element that rapidly marginalize even extinguish is material culture.

Furthermore, Boro et al. (2015) state that globalization has modernized traditional games in terms of tools, rules and structure. Boro et al. (2015) further argue that globalization is a process of international integration arising from the 
world perspective exchange, products, ideas, and other cultural aspects. If people cannot manage themselves well to face the globalization, they will face a great challenge toward their culture and society. In line with this statement, Banol et al. (2016) suggest that traditional game is in extinction due to urbanization and the worldwide introduction of modern games. Though the traditional games is rich of the values and norms such as unity, self-defense and other, the domination of modern games is inevitable. Mutema (2013) states that the traditional game is one of the original knowledge of a society which forms the basis of the livelihood of the community. The traditional game is in a process of extinction due to the influx of western educational system, the advances of technology and its various forms as well as globalization. The traditional game needs to be preserved because it has a fundamental functions to create the children life skills for better environmental awareness.

In the context of Indonesia, the study about traditional games has been conducted by Saddhono and Kuniawan (2017), which examined begalan in Banyumas. Their finding showed that this traditional game was amid friction particularly associated with brenong kepang (kitchen utensil) that became the main equipment in this art. In the past, the commonly used kitchen utensils was fashioned brenong kepong, but today, most of the kitchen appliances are already using modern equipment which according to Banyumas society is more practical and easier to find. Another study was also carried out by Basri (2017) which examined traditional culture of Muna society. The result showed that students at SMAN 1 Kontunaga generally did not know the folklore, failed to memorize Muna song, and could not play its traditional game. The results of this study further confirms that Muna traditional culture including traditional games kalego is in degradation and tends to be forgotten by the community.

In his study about the marginalization of Bajo's culture, Basri et al., (2017) found that one of the factors that led to the traditional culture marginalization was the negative image created by particular majority group toward the minority. In addition, the marginalization of traditional cultures was also found by Arman (2011) and Salniwati (2014). In his study about the expression values of the traditional game ewa Wuna in Muna community, Arman (2011) stated that there were a lot of young generation who do not know ewa Wuna (silat Muna) both in terms its martial/silat movement as well as its values. In addition, older people who understand well about ewa Wuna gradually decreases due to aging factor. Salniwati (2014), which examined the traditional game watawatangke (puzzle) among Muna society indicated that almost all children of primary school age in the Napa Balano District were no longer recognize watawatangke (puzzle) as one of the Muna oral folklore.

\section{Method}

The research was conducted in Watopute District, Muna Regency, Southeast Sulawesi. Informants in this study were the maestro, tribal council, youth, community leaders, and other community members which were determined by using purposive method. The data was collected through: (1) direct observation which carefully observed the informants who play kalego, (2) in-depth interviews to the youth particularly to high school students of SMA 1 Kontunaga and SMA 1 Watopute, educators, community leaders such as religious figures, tribes leaders, youth, especially the conservationists, and other community members, about their ideas, experiences, and knowledge related to kalego, (3) performing experiments about kalego to the informants. Data analysis was conducted qualitatively and descriptive statistic by employing Milles and Huberman's (1991) descriptive-qualitative model through the following steps; (1) data reduction which constructed the units of all collected data from the interviews, observation, literature study, and focus group discussions. The data were filtered, classified, then reduced to eliminate irrelevant data, abstracted and arranged into specific unit; (2) data presentation which categorized and grouped the data into systematic order, arranged connection among categories, compared data categories, and interpreted their relationship; and (3) conclusions which provided interpretations and connection among grouped data categories to draw the interpretation and conclusion. In order to conduct systematic and well-arranged research procedures, the research employed some technical means such as data cards, interview manual, camera or video recorder.

\section{Research Results and Discussion}

\section{A. The discontinuity of Kalego traditional game}

Kalego is one of the traditional games among Muna community which made of coconut shell and staged in groups where each group consists of one player. This game is played by aligning stacked coconut shell side by side where each stack consists of two coconut shell. The stacked coconut shells are then thrown by using another coconut shell. It is uniquely done by clamping it with feet then dilego (swung) to the stacked coconut shells. In the past, this game used as a medium to strengthen the family relationship, to foster the spirit of togetherness, and to provide the community amusements to relieve fatigue after work completion in fields or after pokadu (gotong royong), etc. The game is often played at night and can be played by all age groups ranging from children, adults, and elders. 
However, nowadays, the kalego game apparently tend to be neglected by the community. This trend can be justified from a survey result of 80 Muna residents in Watopute district related to their knowledge of kalego traditional game. It indicated that generally the informants could not demonstrate how to play kalego. The description of their knowledge of kalego traditional game can be observed in Table 1 below.

Table 1. People Knowledge of Kalego Traditional Game

\begin{tabular}{cccccccc}
\hline \multirow{2}{*}{ No. } & \multirow{2}{*}{ Age Range } & \multicolumn{2}{c}{ Informant } & \multicolumn{4}{c}{ Knowledge of Kalego Games } \\
\cline { 3 - 7 } & & Frequency & $\%$ & Recognize Kalego & $\%$ & Can play Kalego & $\%$ \\
\hline 1 & $12-18$ & 20 & 25 & 10 & 50 & - & 0 \\
2 & $19-30$ & 20 & 25 & 20 & 100 & - & 0 \\
3 & $31-40$ & 20 & 25 & 20 & 100 & 100 & 35 \\
4 & $\geq 41$ & 20 & 25 & 20 & 87.5 & 23 & 80 \\
& amount & 80 & 100 & 70 & 28.75 \\
\hline
\end{tabular}

Based on the table, it can be explained that from 20 informants in age range 12-18, 10 informants (50\%) acknowledged kalego game, however, they could not play it, while other 10 informants $(50 \%)$ could not recognize kalego game completely. All 20 informants in age range 19-30 completely (100\%) recognized kalego game, however, they could not play it. All informants in age range 31-40 were familiar with kalego game, however, there were only 7 informants (35\%) who could play it while 13 informants $65 \%$ ) could not. All 20 informants in age range $\geq 41$ were familiar with the kalego game, however, there were only 16 informants (80\%) could play it while other 4 informants $(20 \%)$ could not.

The data also showed that from 80 informants, there were 70 informant (87.5\%), who were familiar with kalego traditional game and there were 10 informants $(12.5 \%)$ were not familiar with the traditional game. Furthermore, from 80 informant, only 23 informants $(28.75 \%)$ who could play kalego traditional game. While 57 informants $(71.25 \%)$ could not play the game. The level of people knowledge on kalego traditional game can be observed in charts 1 and 2 below.

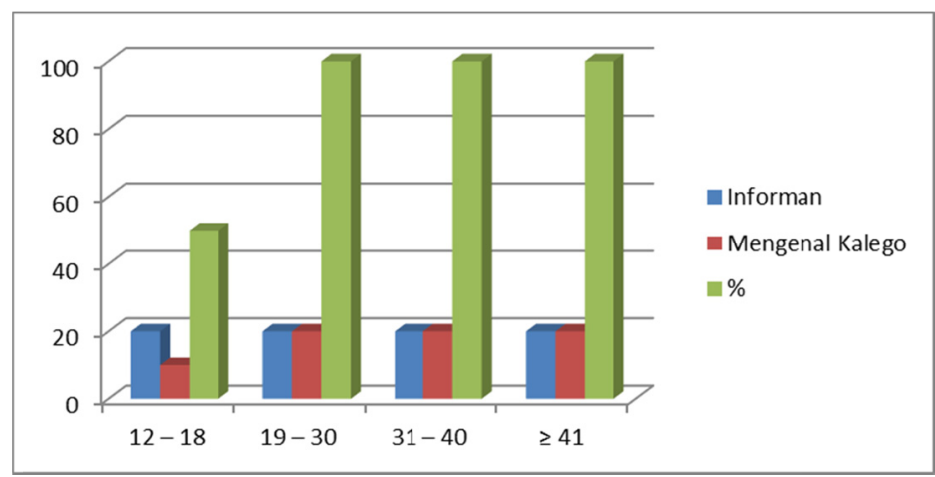

Diagram 1. The number of informants who know the traditional game kalego

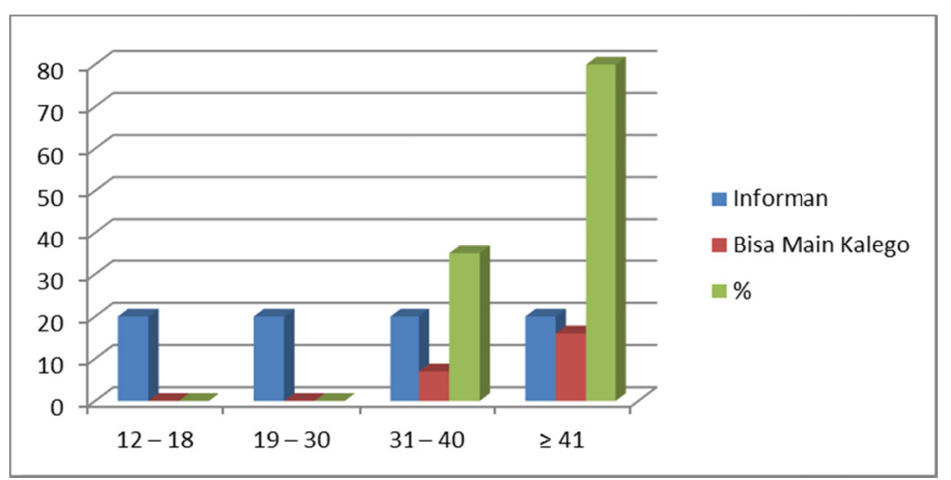

Diagram 2. The number of informants who can demonstrate traditional games kalego

The findings suggested that kalego traditional game is in process of degradation which strongly threatens its existence. This occurs due to some of the following factors. 


\section{The Absence of Kalego Game Inheritance Process in family}

The family is the smallest social unit in society, and this social unit has a function to inherit and protect the values of the local culture. Family is the early stage of acquiring and practicing knowledge. This initial knowledge gained from family significantly contributes to a person's life in wider social practice. With this regard, when the knowledge about a genuine culture is socialized from an early age to a new generation through a system of procreation in the household or family, then the original culture and value will blend with the individuals in each generation. Thus, the local culture will remain preserved and protected without being transformed or vanished by modernization. However, the family function in inheriting and protecting Muna's local culture from the threat of extinction is not employed optimally.

These fact revealed by the findings in this study which showed that generally there were no introduction process toward kalego traditional game. The informant said that the parents were no longer introduced kalego to their children because they generally experienced problems or knowledge limitations about kalego. In addition, their work load as officer also contributed to the lack of original culture inheritance to the new generation. They argued that office tasks were very time-consuming and tiring that influenced their interest to share their cultural knowledge to their children. This situation was also exacerbated by inadequate knowledge about the Muna culture. They thought that discussing Muna culture to their children was very challenging when they had limited comprehension about the culture.

In addition, youth are more familiar and prefer to play other's ethnic arts. For example, they were more familiar with lulo that is originally from Tolakinese dance, or pococo dance, compared to their original traditional game like kalego. This fact is very apprehensive. It may worsen and lead Muna culture into extinction which will only remain known in historical records. This fact further confirms that indigenous Muna communities have been worn away by the modernism which ultimately uprooted them from their original roots. Ali (2007) points out that this situation will eventually lead Muna community loses their tradition. In fact, traditional culture is actually very essential for the existence of a society, even Jayadi (2014) states that local culture is one source of inspiration in everyday life.

Furthermore, Herman (2016) states that in the midst of today's modern culture value crisis, traditional culture becomes a subject of study of various disciplines. It is believed that the traditional culture incorporates the number of indigenous norms, which can be a solution to the crisis of modern culture. One form of indigenous norms in traditional cultures includes the teachings of moral values or human universal values that comes from life experiences and the interaction process of local communities with their surroundings (Mungmachon, 2012), also multicultural education values (Basri et al., 2017). Besides, the traditional culture also comprises a philosophy or leadership tenet (Basrti et al., 2017). These values are not only intended to embody the harmony of living in a society and its culture formation, but also designed to become a life governance tools in the future.

\section{Cultural Values Clash}

The existence of different cultural groups contacts result inevitable cultural diffusion. This process leads to the incorporated acculturation. This term emerges because the acculturation and assimilation process resulted deculturation in Muna society, particularly in the aspect of immaterial culture. This incorporated acculturation particularly showed by Muna's youth attitude which tend to easily embrace other ethnics' cultures than their own culture. Their preference toward molulo, that is originally from Tolakinese immaterial culture, compares to their original traditional arts like kantola, kalego, modero and others is an explicit example of cultural values clash, although both are local cultures. In addition, modernism also becomes part of the cognitive infiltration in Muna community which leads the youth into modern lifestyle. They are more familiar with modern games such as billiards, carom, game console, and others. This phenomenon is in line with Giddens (2003) and Arivia (2004) which argue that the ideology of consumerism culture leads the life of mankind to a pattern of cultural homogeneity that defies parochial values and identity. This threatens the existence of local culture which may destruct or even bring it to the extinction (Giddens, 2005; Steger, 2006). Globalization is very mondial in the sense of encompassing all sides of the remote sides of our global settlement (Piliang, 2004). Thus, Muna society is also a target of globalization.

\section{The Absence of Local Culture Staging and Digitization}

Another factor that contributes to the marginalization of kalego traditional game is the lack of well-arranged kalego staging activities organized by local government or community. In Muna, particularly in Watopote district, kalego game has never been openly performed in the field or in art studio because there is no art studio or cultural gallery in this district. Staging is one way to revitalize and preserve culture to be inherited to the next generation. It can prevent the local culture from extinction as well as preserve the identity of local community 
(Pudentia, 2010). Through the staging, the culture will exist, because a culture cannot be staged if people or players do not have comprehensive understanding about the culture. Therefore, cultural performances or festivals is moment for people to learn and understand their culture. This understanding can only be built through cultural practices which can only be realized when there is a cultural inheritance. The cultural performance agenda is one of the tools for Muna community to learn and know more about their culture.

By cultural performances, the community can build and empower their culture, because people or particularly the cultural supporters, will compete to find out or learn their own culture as preparation for joining a cultural festival. It will trigger the growth of Muna's art and cultural communities. Persistently, the communities will metamorphose into some cultural and art organizations that are managed through art studios. It will increasingly institutionalized and eventually Muna's culture can exist as the result of cultural supporter and preservation community existence.

Beside the absence of well-arranged cultural arts performances activities in Muna, another factor that contributes to the lack of knowledge and concern over kalego traditional game among Muna community is the absence of reconstruction, reinterpretation and actualization of the game through digitization and technological innovation. Muna community commonly consider kalego game as a meaningless past relics. The game generally neglected by the community which leads it to the extinction. They do not realize that cultures, including kalego traditional game, are the new mining deposits which will sustainably exist through continuous exploitation. Culture mining deposits will grow prosperously when they are exploited continuously because they are "renewable deposits". Acknowledged culture will grow rapidly, otherwise neglected or abandoned one will be vanished or extinct.

The statement, of course, has to concern that cultural exploitation as a cultural industry deposit requires a distinguished way to ensure that the mined cultural work remains a clear spring, as a source of inspiration for the emergence of more varied creativity, innovation and new creation. However, Muna community generally have not been able to see culture as one new source of creativity and innovation. In fact, there are ample Muna's cultures which can be created as cultural industry materials through technological innovation to emerge the entrepreneurship and produce a new economic value. It will increase the possibility of cultural preservation and promotion particularly in the mondial era where traditional cultures are continuously advocated to enter the global market and the community are continuously drifted in the consumption culture of products, goods and services. Therefore, the production mode setting is not important, the most important factor is a strategy to campaign the indigenous products into the global market as well as maintain the community supporters from losing their production assets (Ritzer, 2006).

In this globalization era, the process of mutually influencing cultures or interplay of two cultures that resulted cultural change is inevitable. Globalization as an indication of society change struck all the nations over the world. Even becomes a threat and challenge to the integrity of a nation. Muna society, as part of open society, cannot be separated from the influence of this globalization. Thus, the community need to be cautiously aware of this challenge by reacting and well utilizing the global effects in a good and measurable ways as well as preserving Muna community's social order and harmony. In fact, the expansion of global culture indirectly opens the space for awareness of local and regional cultures, and stimulate local cultural dynamics and strategies in response to globalization (Nashir, 1999).

\section{Conclusion}

Kalego traditional game in Watopute district of Muna regency was in process of discontinuity and possibly lead to the extinction. The unsustainability of Muna local culture was caused by some fundamental factors; 1) the absence of the family inheritance process to introduce local culture and the decreasing number of old figures who understand Muna culture which contributed to the decreasing of local culture knowledge among younger generations; 2) cultural clashes which resulted incorporated acculturation toward Muna's local culture; 3) the absence of the massive Muna's local culture staging.

\section{References}

Ali, M. (2007). Orang Desa Anak Tiri Perubahan. Malang: Averroes Press.

Arivia, G. (2004). Mencari Kesadaran Baru untuk Mendapatkan Peradaban Baru. Dalam: Jalan Paradoks Visi Baru Fritjof Capra tentang Kearifan dan kehidupan Modern. Penyunting: Budi Munawar R dan Eko Wijayanto. Jakarta: Teraju.

Arman. (2011). Nilai-Nilai Tuturan Tentang Ewa pada Masyarakat Muna (Unpublished master's thesis). Halu Oleo University, Kendari, Indonesia.

Banol, Surryia, Gul, Nasreen, Rodenill, A. Y., Akhte, J., \& Baloch, H. A. (2016). The Importance of the Sports 
in Baloch Society: A Cultural Perspective. International Journal of Sports Science, 6(2), 66-69. https://doi.org/10.5923/j.sports.20160602.08.

Basri, A. O. L., Aso, L, Momo, H., A, Mudana, Wayan, I, Taena, L, Salniwati, Janu, L., \& Aswati. (2017). The Valuas of Multicultural Education in Munanese Traditional Culture. Asian Culture and History, 9(1), 33-39. https://doi.org/10.5539/ach.v9nlp33

Basri, A. O. L., Mudana, Wayan, I., \& Rahman, A. (2017). The Negative Stigma Against the Bajo Tribe and its Impact on Local Culture: Study of the Bajo Tribe in Bungin Village of South Konawe. Asian Culture and History, 9(2), 90-95. https://doi.org/10.5539/ach.v9n2p90

Basri, A. O. L., Momo, A. H., Marhadi, A., Rahman, A., \& Aswati. (2017). Concept and Leadership Style in the Story of Munanese Folklore: A Study to the Fairy Tale of Kolope Bhala Tumbu (Gadung/Dioscorea Hispida Dennst). Asian Culture \& History, 9(2), 83-89. https://doi.org/10.5539/ach.v9n2p83

Basri, A. O. L., Momo, H. A., \& Rahman, A. (2017). Strategi Pelestarian Budaya Lokal Masyarakat Muna. Laporan Hasil Penelitian. Kendari: LPPM UHO.

Boro, J., Daimary, R., \& Narzaree, B. (2015). Impact of Globalisation to Traditional Games and Recreation of the Bodos. Journal of Humanities and Social Science, 2(3), 87-91. https://doi.org/10.9790/0837-20338791.

Escobar, A. (2001). Culture Sits in Places: Reflections on Globalism and Subaltern Strategies of Localization. Political Geography, 20, 139-174. https://doi.org/10.1016/S0962-6298(00)00064-0

Giddens, A. (2003). Masyarakat Post-Tradisional. Penerjemah: Ali Noer Zaman. Yogyakarta: IRCiSoD. . (2005). Konsekuensi-Konsekuensi Modernitas. Yogyakarta: Kreasi Wacana.

Herman, K. D. R. (2016). Traditional knowledge in a time of crisis: climate change, culture and communication. Sustainability Science, 11(1), 163-176. https://doi.org/10.1007/s11625-015-0305-9

Jayadi, K. (2014). Kebudayaan sebagai Sumber Inspirasi: Tinjauan Antropologi Visual pada Pelukis di Kota Makassar. Gelar, 12(2), 115-128.

Premo, L., dan Khun, S., \& Steven, L. (2010). Modeling Effects of Local Extinctions on Culture Change and Diversity in the Paleolithic. Plos One, 5(12), 1-10. https://doi.org/10.1371/journal.pone.0015582

Nashir, H. (1999). Agama dan Krisis Kemanusiaan Modern. Yogyakarta: Pustaka Pelajar.

Milles, M. B., \& Huberman, dan A. M. (1992). Analisis Data Kualitatif. Jakarta: UI.

Mungmachon, R. M. (2012). Knowledge and Local Wisdom: Community Treasure. International Journal of Humanities and Social Science, 2(13), 174-181.

Mutema, F. (2013). Shona Traditional Children's Games and Songs as a Form of Indigenous Knowledge: An Endangered Genre. Journal of Humanities and Social Science. 15(3), 59-64.

Pudentia, M. P. S. S. (2010). The Revitalization of Mak Yong in the Malay Word. Wacana, Journal of the Humanities of Indonesia, 12(1), 1-19. https://doi.org/10.17510/wjhi.v12i1.41

Piliang, Y. A. (2004). Dunia yang Dilipat: Tamsya Melampaui Batas-Batas Kebudayaan. Yogyakarta: Jalasutra

Ritzer, G. (2006). Teori Sosial Postmodern. Yogyakarta: Kreasi wacana.

Saddhono, K., \& dan Kuniawan, A. (2017). Islamic religious value in traditional ceremony of Begalan Banyumasan as educational character for student at senior high schools in central Java. UMRAN. 4(1), 71-77.

Salniwati. (2013). Wawata watangke Tradisi Lisan Etnis Muna. Tesis PPs UHO, Kendari.

Sibarani, R. (2012). Kearifan Lokal Hakikat Peran dan Metode Tradisi Lisan. Jakarta: Asosiasi Tradisi Lisan.

Steger, M. B. (2006). Globalisme Bangkitnya Ideologi Pasar. Yogyakarta: Lafadl Pustaka.

Wahab, E. O., Odunsi, S. O., \& dan Ajiboye, O. E. (2012). Causes and Consequences of Rapid Erosion of Cultural Values in a Traditional African Society. J. of Anthropology, 12, 1-7. https://doi.org/10.1155/2012/327061

\section{Copyrights}

Copyright for this article is retained by the author(s), with first publication rights granted to the journal.

This is an open-access article distributed under the terms and conditions of the Creative Commons Attribution license (http://creativecommons.org/licenses/by/4.0/). 